\title{
Balancing Transparency and Privacy in a University Sexual Misconduct Case: A Legal Public Relations Case Study
}

\author{
Chelsea L. Woods ${ }^{1} \odot$, and Shari R. Veil ${ }^{2}$
}

1. Department of Communication, Virginia Polytechnic Institute and State University, Blacksburg, Virginia, USA

2. Department of Communication and Undergraduate Affairs, College of Communication and Information, University of Kentucky, Lexington, Kentucky, USA

\begin{abstract}
In 2016, the University of Kentucky became embroiled in an open records debate with its student newspaper, The Kentucky Kernel. Following a professor's resignation amid a sexual misconduct investigation, the Kernel asked for records pertaining to the case. The University refused, claiming the information would violate survivors' privacy. The decision sparked public backlash, forcing the University to combat accusations that it was prioritizing reputation over student safety. This case study provides insight into the crisis management process by exploring how key actors in the case made decisions. Drawing from theoretical perspectives including stakeholder theory and the ethics of care and justice, this study explores the complexities of addressing incongruent stakeholder perspectives and balancing stakeholder interests, along with offering implications for public relations practitioners.
\end{abstract}

KEYWORDS: legal crisis, public relations, crisis communication, stakeholder theory, ethics

In 2016, the University of Kentucky made national headlines amid a public legal battle with its student newspaper, The Kentucky Kernel. The Kernel filed an open records request with the University to obtain documents detailing a sexual misconduct investigation of a tenured associate professor. The University refused, claiming that releasing the information would violate

CONTACTChelsea L.Woods (D) • clwoods@vt.edu • Department of Communication, Virginia Polytechnic Institute and State University, 110 Shanks Hall (0311), 181 Turner St NW, Blacksburg VA 24061 
the Family Education Rights and Privacy Act (FERPA) because it would allow for the identification of the graduate student complainants. The Kentucky Attorney General sided with the Kernel and ordered the release of the name-redacted records. To appeal the ruling, the University sued the paper. In the announcement of the lawsuit, University President Eli Capilouto acknowledged the tension of "safeguarding" survivors' privacy while recognizing "the need for transparency" (Capilouto, 2016a, para. 1). The Kernel staff claimed the University was more concerned with protecting its reputation than its students (Editorial Board, 2016a, 2016b).

Like any organization, institutions of higher education are susceptible to crises, and "higher education leaders face the added challenge of addressing potential gaps that a crisis may reveal relative to the core values of an institution" (Fortunato et al., 2018, p. 510). University communicators must protect reputations and stakeholder relationships (Varma, 2011). Many institutions, such as the University of Kentucky, are also public entities. Thus, the crisis can also affect relationships with government agencies and create an expectation that because it is a public institution, it must be held to a higher standard (Len-Ríos, 2010).

Despite the recent emergence of crisis communication studies in sexual misconduct cases on college campuses, Madden (2018) proclaimed that little research offers guidance for how communicators "can most effectively deal with the gendered and emotional dimensions" of these issues (p. 596). Survivors cite privacy and confidentiality concerns as reasons why they choose not to report incidents (Trades Union Congress [TUC], 2016). The calls for confidentiality in sexual misconduct cases, which often include a male perpetrator in a position of power victimizing a female, point to the notion that privacy is gendered (Higgins, 1999; Roth, 1999). Researchers have found that "certain issues important to women," such as sexual misconduct, "have traditionally been deemed private" (Goldfarb, 2000, p. 1), and judicial procedures involving these issues are seen more as individual issues than societal issues (MacKinnon, 1991). Gotell (2006) argued that "the discourse of privacy has served to mask violence, inequality, and subordination" (p. 747). While arguments for privacy are seemingly made to protect survivors, keeping sexual misconduct cases private 
perpetuates the victimization of women by not publicly holding perpetrators accountable for their actions.

The case of University of Kentucky vs. The Kentucky Kernel exemplifies these challenges as critics attacked the institution over its lack of transparency and alleged that its misplaced priorities endangered students. We apply stakeholder theory and the ethics of justice and care to extend our knowledge of crisis communication in legal crises broadly and sexual misconduct cases specifically. Using a robust case study approach (Sellnow, Littlefield, et al., 2009), we draw from multiple data points, including interviews with decision-makers at the University of Kentucky and the Kernel, the University's official statements, and reports from the Kernel and other media sources. By speaking with the decisionmakers, this study offers a better understanding of how individuals make decisions in legal crises (Fitzpatrick \& Rubin, 1995), specifically when addressing issues such as privacy and transparency in sexual misconduct cases.

\section{Literature Review}

\section{Crisis Communication in Sexual Misconduct Cases}

Crisis communication scholars have identified five primary response strategies in legal crises: denial, excuse, justification, concession, and diversion (Benoit, 1995; Coombs, 2007; Huang et al., 2005). Huang et al. (2005) placed the strategies on a continuum ranging from defensive, which favors organizational interests and includes denial, to accommodative, where organizations show concern for victims and invoke concession strategies. Research suggests legal practitioners favor defensive strategies, advising clients to remain silent (Fitzpatrick \& Rubin, 1995; Gibson \& Padilla, 1999). Crisis communication scholars emphasize a more accommodative stance including openly and honestly communicating, along with engaging in corrective action, which could be considered a concession strategy (Seeger, 2006). The tension between legal practice and crisis research recommendations is evident in the University of Kentucky sexual misconduct case whereby the University claimed it could not be transparent and accommodating because of its concern for the legal right of survivor privacy. 
Recent research has focused on legal crisis communication in sexual misconduct cases on college campuses (Madden, 2018), including the Duke University lacrosse (Fortunato, 2008; Jin et al., 2010; Len-Ríos, 2010) and Penn State football cases (Brown et al., 2015; Formentin et al., 2017). Scholars have emphasized the importance of identifying "critical stakeholders" during sexual misconduct crises, noting that how these individuals evaluate the university's response impacts the university's reputation (Fortunato, 2008). For example, Duke University identified key stakeholder groups and adjusted its communication strategies depending on the stakeholder group (Jin et al., 2010). However, Duke's decision to refrain from involvement in criminal justice allegations prohibited it from satisfying all of its stakeholders, underscoring the challenge of balancing stakeholder interests during a crisis (Len-Ríos, 2010). In order to further explore the tension between legal crisis communication and balancing stakeholder interest under the circumstances of sexual misconduct and harassment cases, this study poses the following research question:

RQ1: What communication strategies did the University employ in response to the crisis, and how did stakeholders respond?

\section{Managing Stakeholder Interests}

To understand how the University of Kentucky attempted to balance stakeholder interests in this case, we turn to stakeholder theory, which considers how organizations affect and are affected by groups including customers, employees, the media, and the government (Freeman, 1984). Crises require the organization to work with stakeholders to manage outcomes (Ulmer, 2001). Stakeholders can pressure an organization throughout the crisis by asking for information, demanding answers, and seeking resolution (van der Meer et al., 2017). Crises that produce conflicting stakeholder desires complicate the response process. Len-Ríos (2010) contended that universities in particular "must make strategic decisions regarding prioritizing publics" to meet the needs of their "broad array of constituents" (p. 269). 
A prominent framework introduced to classify stakeholders is Mitchell et al.s (1997) theory of stakeholder salience and identification, which offered a typology of stakeholders using three relational dimensions: urgency, power, and legitimacy. The theory posits that the more attributes a stakeholder holds, the more salient the stakeholder becomes from a managerial perspective. Urgency reflects "the degree to which stakeholder claims call for immediate attention" (Mitchell et al., 1997, p. 867). Power embodies the ability to convince an organization to do something that it would not do otherwise (Alpaslan et al., 2009). Finally, a stakeholder wields legitimacy if their actions or claims about the organization are "desirable, proper or appropriate" within a social system (Suchman, 1995, p. 574). As the circumstances surrounding the crisis change, so do stakeholders' needs and salience.

Other "ethical" approaches to stakeholder management during a crisis argue that "the decision to include a stakeholder in crisis preparation and response should not be based solely on that stakeholder's salience" (Alpaslan et al., 2009, p. 43; Xu \& Li, 2013). Organizations often prioritize certain stakeholders during a crisis, but such action should be taken based on the extent of personal impact (Ulmer \& Sellnow, 2000). To embrace this "ethical approach," organizations must attend to all affected stakeholders (Ulmer, 2001), prioritize stakeholders based on the situation and shift these priorities as the situation evolves ( $\mathrm{Xu} \mathrm{\&} \mathrm{Li,} \mathrm{2013),}$ and make decisions that fairly consider and reflect all stakeholder interests (Sandin, 2009; Ulmer \& Sellnow, 2000).

This study thereby proposes the following question:

RQ2: What stakeholder group(s) did the University prioritize?

\section{Ethical Approaches}

To balance competing stakeholder interests, an organization engages in a decision-making process. But "without an ethical compass to guide its decisions," an organization may employ strategies that violate stakeholder expectations (Tao \& Kim, 2017, p. 698), straining its stakeholder relationships and jeopardizing its legitimacy. Two ethical approaches that outline how an organization can respond to stakeholder pressure are the ethics of justice and care. 
An ethic of justice emerged from social justice theory, which argues for individuals to be held to universal laws (Rawls, 1971). An ethic of justice requires that an organization treat all stakeholders fairly by making impartial decisions that recognize the interests of all stakeholders involved in the crisis (Sandin, 2009). The organization acts objectively and embraces rationality, scientific approaches, and individual rights (Simola, 2003; Tao \& Kim, 2017), drawing upon arguments grounded in logic and objectivity (Kim et al., 2016). However, scholars have also suggested that using universal rules may not account for nuances in crises, limiting an ethic of justice's applicability in crises (Simola, 2003; Tao \& Kim, 2017).

An ethic of care emphasizes nurturing relationships and expressing values such as compassion and empathy (Fraustino \& Kennedy, 2018; Kim et al., 2016; Tao \& Kim, 2017). This approach entails "concern about how to fulfill conflicting responsibilities to different people, as opposed to questions of how to resolve claims of conflicting rights among them" (Simola, 2003, p. 354). An ethic of care approach was a critical response to the justice approach (Simola, 2003; Tao \& Kim, 2017). Crafted by Gilligan (1977), an ethic of care emerged from a feminist perspective, grounded in Gilligan's research that found women valued contextual and relational factors when making moral decisions. Gilligan (1982) argued a justice-driven approach is too rigid to account for the complexity of moral dilemmas. An ethic of care "considers the contextual complexities" of crisis and prioritizes those who have been affected (Linsley \& Slack, 2013; Simola, 2003, p. 354), implying an organization should be involved and remain "sensitive and responsive to the emotional feelings and needs of publics" (Tao \& Kim, 2017, p. 693). Considering the different ethical approaches to balancing stakeholder interests, especially in the dynamics of a crisis, this study poses the following question:

RQ3: How did the University incorporate an ethic of justice and an ethic of care in its crisis responses?

\section{Methods}

This study aims to understand how organizational decisionmakers navigate challenging legal and ethical quandaries while 
illustrating how stakeholder values can conflict with organizational obligations. We used a robust case study approach, which enables researchers to make claims about a situation using multiple sources of information (Sellnow, Littlefield, et al., 2009). Case studies are useful when the research examines a current event by allowing "investigators to retain the holistic and meaningful characteristics" (Yin, 2009, p. 4) to derive practical implications (Patton, 2002). This case examines the crisis communication challenges faced by the University of Kentucky when its handling of a sexual misconduct case generated allegations that it was acting irresponsibly.

For data triangulation, we included statements released by the University of Kentucky on uknow.uky.edu $(n=7)$, emails from the University president to faculty, staff, and students $(n=3)$, articles published by the Kernel $(n=47)$ and local newspaper The HeraldLeader $(n=32)$, and articles culled in a Google News search using the terms "University of Kentucky," "Kernel," and "sexual misconduct" $(n=45)$. All documents were collected from April 6, 2016, when the Kernel published its first article, to May 17, 2019, when the Appeals Court ruled in favor of the Kernel. After receiving approval from the Institutional Review Board, we conducted face-to-face interviews with four individuals who were involved in decision-making processes. These individuals were the unnamed member of the University of Kentucky's legal counsel, who provided legal advice during the case; Jay Blanton, the executive director of public relations and marketing, who handled media inquiries on behalf of the University; Marjorie Kirk, the former Kernel editor, who wrote many of the stories about the case and made decisions about what information to publish; and Chris Poore, the former Kernel advisor, who said he offered advice to student journalists but allowed them to make the final decisions. All participants except legal counsel consented to have their names included in the write-up of the study.

We used semi-structured interviews to compare answers across the sample, adjusted questions based on the interviewers' affiliation (the University or the Kernel), and asked follow-up questions (Patton, 2002). Questions for participants from the Kernel focused on the staff's concern with the University's public response, how 
it expressed these concerns to administration, and the challenges the staff faces in covering sexual misconduct cases. Questions for University decision-makers centered on the factors that influenced the University's public response to the case, the challenges the University faced when communicating about these types of cases, and how maintaining the University's reputation factored into these decisions. Interviews ranged from 41 to 98 minutes and were audio-recorded with permission from the participants.

After collecting data and transcribing the interviews, we conducted textual analysis (Creswell, 2013). First, all data were read to achieve a holistic understanding of the case while making initial notes and observations. Second, the data were re-read multiple times to form preliminary codes, which were grouped and placed into larger categories or themes, combining codes as needed to avoid duplication. Finally, a reading of the data was conducted to ensure all evidence supported its assigned theme. The resulting analysis is described next.

\section{Case Background}

In February 2016, a University of Kentucky professor signed a resignation agreement following a sexual misconduct investigation comprising three allegations, two complainants, and five survivors. The case (Table 1) began when a spokesperson representing two female survivors approached then-Kernel reporter Marjorie Kirk (Kirk, personal communication). At first, the paper could only report on the settlement statement shared by the University, which refused to release the full report (legal counsel, personal communication), claiming it would "constitute an unwarranted invasion of personal privacy" (Smith, 2016, para. 5). Revoking tenure can take years. The University's push for resignation offered a quick solution, but once the accused leaves the university, the inquiry essentially ends (Kirk, 2016b). Because many settlements prohibit disclosing the incident to future employers, the "passing the trash" practice permits faculty to move without public knowledge of accusations (Rexroat, 2017). The survivors feared the professor would repeat the behavior at another institution (Kirk, personal communication). 


\section{TABLE 1 Timeline of Events}

$\begin{array}{ll}\text { February 2016 } & \begin{array}{l}\text { Accused professor signs an agreement with the } \\ \text { University of Kentucky (Smith, 2016). } \\ \text { Two survivors approach Kirk regarding their } \\ \text { March 2016 }\end{array} \\ \text { concerns with the settlement (Westerman, 2017). } \\ \text { The Kernel publishes its first article on the case and } \\ \text { asks the University for records pertaining to the } \\ \text { case (Kirk \& Wright, 2016). } \\ \text { The University provides a letter of the investigation. } \\ \text { The Kernel files an appeal with the Attorney } \\ \text { General's office to release the documents (Smith, } \\ \text { 2016). } \\ \text { The Attorney General rules the University should } \\ \text { release the documents but redact the names and } \\ \text { identifiers of the complainants and witnesses (News } \\ \text { Staff, 2016). } \\ \text { The University announces its decision to sue the } \\ \text { Kernel as part of the appeals process (Kirk \& Wright, } \\ \text { 2016). } \\ \text { The Kernel obtains 122 pages of records from a } \\ \text { confidential source representing the two survivors } \\ \text { (Kaufman, 2016). } \\ \text { The University confirms its decision to proceed with } \\ \text { the lawsuit. } \\ \text { The University files suit against the Kernel. }\end{array}$




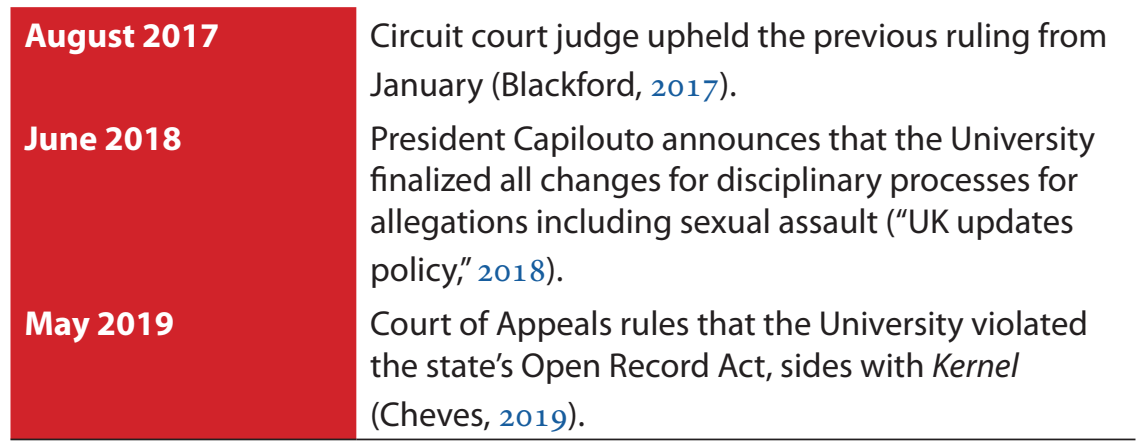

Early media coverage was impeded by the University's decision to only provide the settlement statement, reportedly frustrating two survivors (Kirk, personal communication). Kirk and the then-editor of the Kernel filed an open records request with the Attorney General (Kirk \& Wright, 2016), who ruled the University should release the documents to the Kernel and the Attorney General's office but redact the names and identifiers of complainants and witnesses (News Staff, 2016). The University declined and, in accordance with state law, announced it would sue the paper to appeal the decision, leading the two survivors to give several pages of redacted records to the Kernel (Kirk, personal communication). Kirk warned the survivors that "this story's probably going to take off," anticipating the local newspaper would be interested but not that it would quickly gain national attention (personal communication).

\section{Findings}

RQ1: University Response and Stakeholder Reactions

Secrets "stain" the university's image. The University applied the excuse strategy by using provocation, presenting its actions as the appropriate legal response (Huang et al., 2005). Following an allegation, the University must investigate. If the investigation reveals an incident did occur, the University initiates a three-step process: stop the activity, mitigate the effects, and ensure it never happens again "on our campus" (legal counsel, personal communication). 
The University must provide due process and can only remove the accused (legal counsel, personal communication). According to University spokesperson Jay Blanton, settling was the fastest way to legally remove the threat, even if it "was imperfect" (personal communication). The University also sued the Kernel to avoid releasing the redacted documents, which it said contained enough information to identify the complainants and witnesses. Blanton recognized the courts were necessary to reconcile the competing tensions of transparency and privacy (personal communication), and University legal counsel added that "naming the Kernel is a quirk of Kentucky law. Our dispute is with the Attorney General" (personal communication).

The case gained national media attention (Kaufman, 2016), even though the University's decision to sue is a common practice between journalists and public institutions according to Kernel advisor Chris Poore (personal communication). Some stakeholders supported the University, including on-campus survivors' advocacy group SPARC, which argued that transparency should not jeopardize survivors' "privacy and dignity" (Melanson, 2016, para. 22). But conveying the legalities of the situation proved problematic as the University's proclaimed desire to protect individuals was overshadowed by claims that it "is fighting for secrecy, not for privacy. It is fighting for itself, not for victims" (Editorial Board, 2016b, para. 32).

A local journalist claimed nearly all the media attention was critical (Blackford, 2016d). The Kernel called the case "a stain on the University's image” (Editorial Board, 2016a, para. 20), and external agencies deemed it "embarrassing" (Merlan, 2016, para. 2). The Kernel accused the University of hiding information (Editorial Board, 2016a) and safeguarding its own image (Editorial Board, 2016b). Reporters highlighted the University's status as a public institution, contending this position made its behavior more egregious (News Staff, 2016). This veil of secrecy was fed by what Poore labeled "the Blanton funnel" (personal communication). Poore expounded that "You only have one source for a story on campus. That's Jay Blanton," which often produces a "washed out" rather than "accurate version of the story." Kirk added that for 
the majority of the case, only Blanton's office would speak with the Kernel, which she felt made it appear as though the University was "responding to a public image concern, not an administrative or a disciplinary concern" (personal communication).

Following legal precedent or hiding behind the law? The University attempted to act with good intentions by citing the Family Educational Rights and Privacy Act (FERPA). Because the University receives federal funds, it must adhere to the federal law, which "precludes us from revealing educational records without the consent of everyone involved" and broadly defines an educational record "as essentially any document maintained by the University that relates to a student" (legal counsel, personal communication). According to legal counsel, the law required the University to retain all records, even if redacted. The ability to access information online also influenced the University's decision as administration determined it was "effectively impossible" to redact all identifying details (legal counsel, personal communication) and feared the justice system could not guarantee confidentiality to prevent retaliation (Westerman, 2017). University legal counsel emphasized it acted "with guidance from the U.S. Department of Education in 2006," which stated "you cannot turn over FERPA protected documents to a State Attorney General in the context of an open records dispute" (personal communication). Legal counsel added that the University provided a description of the documents to the Attorney General.

Citing FERPA added a new tension. Critics stated the University overstepped its bounds as the decision about what documents can be released "is the job of the legal system, not the University President” (Editorial Board, 2016b, para. 23). Others argued the use of FERPA made the University the "latest example of colleges hiding behind student privacy laws to protect their image and reputation" (New, 2017, para. 3). Both Kirk and Poore claimed other universities provided documents in similar cases and were not punished (personal communication).

Blanton and the legal counsel were "disappointed" that media coverage never noted the complexity of the University's decision as "there never seemed to be an acknowledgment that the University wasn't just making this up. We were, in effect, following 
well-established law" (legal counsel, personal communication). Blanton also claimed the media failed to recognize the University's precarious situation by including "scant" mention of the legal-privacy tension and disproportionately focusing on the open records debate (personal communication). Conversely, the Kernel frequently questioned why administrators would not release a redacted report as a form of compromise (Editorial Board, 2016a; Kirk, 2016a). Kirk claimed names and event descriptions are unnecessary as "you would just need to know that [the professor] was found responsible by his employers for doing this, this, and this ... That page has nothing on it that you could even argue was an education record" (personal communication).

The university's redaction blunder. The survivors later changed their stance and sided with the University as the case gained national attention, believing that "the line between the laudable goal of transparency and the blatant invasion of privacy has been crossed" (Blackford, 2016d, para. 3). But this turn of events was overshadowed by a University gaffe. At its Board of Trustees meeting, the University distributed letters written by the survivors expressing their "dissatisfaction" with the media coverage, but when removing identifying information, overlooked one reference that identified a survivor (legal counsel, personal communication). Kirk, who attended the meeting, caught the mistake and brought it to the attention of Blanton (Kirk, personal communication), who swiftly collected the letters and later apologized to the survivors (Blanton, personal communication). The media capitalized on the mishap, emphasizing that "UK is the only one that has identified a victim by name" (Editorial Board, 2016b, para. 20).

Selling salacious news. During the same Board of Trustees meeting, President Eli Capilouto escalated criticism when he stated that "In printing salacious details to attract readers, they [the Kernel] have effectively identified the victim survivors" (Blackford, 2016b, para. 12). Blanton explained that Capilouto meant not all details need to be included to print the story (personal communication). Nevertheless, the damage was done, and Capilouto's use of the attacking the accuser strategy backfired. Many saw his comment as a direct attack on Kirk. Even though Capilouto did not explicitly name Kirk, she was the paper's "decision maker" (Kirk, 
personal communication). For Poore, "UK was fine as they were arguing it as a policy issue. When Dr. Capilouto made it about the person, he went way too far" (personal communication).

Journalism faculty at the University penned a letter requesting an apology (Stripling, 2016). Capilouto refused, arguing that "to have a student newspaper provide so much information in an article that anybody in 15 minutes could most likely identify the victims of assault" is "a serious matter" (para. 47). Kirk said she conferred with the survivors about the details included in the articles, such as the professor's behavior at conferences, and received their approval (personal communication). Poore explained that without those details, the survivors feared that "people wouldn't realize the setting he had done that in" and thus, assertions that they could be readily identified "was pretty unfair treatment" of Kirk (personal communication).

Corrective action. The University invoked concession by announcing systemic changes. Early on, administrators used corrective action by declaring that it would require new faculty members to share their sexual misconduct history and offer training to graduate students and their mentors (Capilouto, 2016b). The University also introduced a process for reviewing faculty behavior following "clear examples of sexual misconduct" (para. 11). Yet, thus far, a required training session has only been offered to graduate students and not their faculty advisors. While other steps, such as the revised disciplinary process, show commitment to addressing University members' "concerns and suggestions" ("UK updates policy," 2018, para. 2), it must implement all of its plans to address the "passing the trash" problem at the university level.

RQ2: Stakeholder Priorities

The University publicly identified its salient stakeholders to be (1) the survivors, and (2) current students. The University of Kentucky maintained its decisions were to protect the survivors' privacy while adhering to legal obligations. Legal counsel emphasized the Kernel provided details, such as "the fact that they were Ph.D. students," noting that the University posts dissertations online with advisor names (personal communication). Thus, "If 
you wanted to look back and see how many students got a Ph.D. in a particular field, you could do so in a matter of moments." The University voiced that "truly honoring the value of transparency" required letting the survivors make decisions about sharing details (Manouchehri, 2016, para. 12).

First, as part of the University's three-pronged response to sexual misconduct (stop, mitigate, prevent), it emphasized that its responsibility is to survivors, and that removing the threat to protect these stakeholders was paramount (Blanton, personal communication; legal counsel, personal communication). Second, the administration claimed that protecting survivor privacy in this case was necessary to establish a climate where other survivors would feel safe to report incidents. In an email, Capilouto (2017) asserted that "Without privacy, we know victim survivors will not come forward to report. That's what was at stake in this case" (para. 3).

Critics maintained that the University was prioritizing itself and neglecting "other students and the public" (Kirk, 2016a, para. 1). The Kernel's Editorial Board (2016a) offered that the University's denial of the open records request "showed it cares more about its own interests than it cares about the law, accountability or the public's right to information" (para. 13). Critics also claimed that the University's response prioritized the accused over the survivors and other stakeholders. Early on, a spokesperson for the two survivors argued:

It feels like UK is trying to protect what went on here and to protect [the professor]. Why not have complete transparency in this?... UK should be interested in protecting not just the students at UK. (UK) should also be in the interest of protecting students at other universities where [the professor] may end up. (Kirk, 2016a, para. 15)

The Editorial Board (2016b) echoed this claim, asserting that "The university gives the accused privacy in matters the public has a right to know" (para. 10).

RQ3: Ethical Approaches

Several of the University's decisions and communications reflected an ethic of justice by underscoring fairness, protecting rights of 
all involved parties, and employing legal reasoning. First, Blanton emphasized that individuals have a right to due process and recognized that the University has a responsibility to create fairness for the accuser and accused (personal communication). Second, the University relied on logical reasoning by citing laws, reflecting an attempt to objectively evaluate a conflict. Although the University cited FERPA to justify not releasing the records, legal counsel also explained that "in the sixth circuit, the constitutional right to privacy extends to the details of a sexual misconduct except where the disclosure of those details is necessary for a criminal prosecution" (personal communication). Thus, "FERPA aside, if instead of students, these were departmental secretaries or non-students who were alleging sexual misconduct, we could not as a governmental entity turn that information over."

Although the University tried to determine what the law required, Blanton explained that legal codes are "not always 100\% clear. Judgments have to be made" (personal communication). When making the judgment call, the University "landed on the side of the victims' rights to tell their story," including when and how (personal communication), permitting it to employ an ethic of care approach by maintaining that its response was an effort to do what was right for the survivors. Blanton emphasized that these decisions were based on the survivors' needs, claiming the University "cannot-and should not-decide when it is appropriate to violate a victim-survivor's privacy-and a victim-survivor's trustby providing information to the Office of the Attorney General, the Kernel, or any other entity" (Blackford, 2016a, para. 11).

President Capilouto (2016a) underscored relational aspects when he asserted that "we believe strongly in the need to protect the privacy of members of our community: our students, patients, faculty, and staff" (para. 3). During the Board of Trustees meeting, he maintained that the University was trying to remain sensitive to the needs of the survivors and support them:

It is essential that the victim survivors of sexual misconduct know that their University stands with them, embracing them when they come forward in the courageous effort at justice and at healing; and that we will do everything in our power to protect their privacy. . . . (Melanson, 2016, para. 17) 
Capilouto (2016a) also claimed that the University ponders the needs of affected stakeholders. He expounded that the University annually receives hundreds of open records requests and complies with most, but makes circumstantial decisions when deciding between transparency or protecting "the privacy and dignity of individual members of our community" (para. 7).

\section{Discussion and Implications}

Madden (2018) claimed university-led discussions about sexual misconduct "call into question who is being valued and why" and added that "it could become problematic if protecting the institution and institutional values supersedes the protection of individuals" (p. 305). This statement captures the essence of the University of Kentucky case as the administration maintained that its priorities lay with protecting the privacy of the survivors while many of its stakeholders, including the Kernel, argued that it was pursuing self-interest and secrecy. Using stakeholder theory and ethical approaches, we explore the theoretical applications in this case before describing the larger social implications and offering suggestions for practice.

\section{Theoretical Applications}

A stakeholder approach. Power, legitimacy, and urgency were crucial to the case's evolution (Mitchell et al., 1997). Although the two survivors reported the professor, leading to his resignation, no further action occurred at the University level. After publishing a handful of articles and filing the open records request, the Kernel gained a foothold. Shortly thereafter, the alliance of the Kernel and two survivors, followed by the newsworthy aspect of the University's decision to sue the Kernel, shifted the balance of power in the favor of the Kernel. Further, the Kernel claimed its access to the documents, thanks to the survivors, meant the University's message "of fighting for the privacy of its victims" fell apart (Editorial Board, 2016a, para. 20), lending legitimacy to the paper's request. The amount of attention given to the case and stakeholder pressure on the University added a degree of urgency, pushing it to announce changes to minimize the risk of sexual 
misconduct on campus in September 2016. Although Blanton said the adjustments were already under review (Horsley, 2016), Kirk (2016c) claimed the step came "only after the university felt pressure and criticism" (para. 16) from stakeholders.

External media narratives reflected sentiments expressed by the Kernel, seemingly delegitimizing the University's stance as reporters criticized the validity of the legal arguments, portraying them as "a smokescreen" (New, 2017, para. 14). Some stakeholders doubted the legitimacy of the institution itself by raising questions about its values, arguing its actions were irresponsible and tried "to block sexual assault reporting" (Higdon, 2016, para. 1). Legal rulings throughout the case also shifted the tide of legitimacy arguments. In 2017, the University received support when the circuit court ruled in its favor, prompting a sizable decline in external media coverage. The survivors' decision to join the University in the lawsuit after the case received substantial publicity, expressing concern that disclosing additional records would allow the media or others to uncover their identities (Blackford, 2016d), and also altered the trajectory as those who were the most directly affected by the University's decisions now stood with it.

Although the Kernel's persistence in pressuring the University to release the information made it, along with others, a salient stakeholder, the University refused to budge and relied on an ethical stakeholder argument (Xu \& Li, 2013). The administration fervently maintained that its efforts were to protect those most affected by the crisis, the survivors, from the onset when the University removed the accused. The University had to operate within legal parameters that required some details to be withheld while responding to public pressure to release information. The situation created a legal-ethical tension since releasing information would place the survivors at risk and, according to the University, violate federal law. However, withholding the information could endanger other individuals and violate the Open Records Act. The University's unwillingness to release certain documents out of a proclaimed interest to protect the survivors hindered it from taking action that reflected the interests of all stakeholders (Sandin, 2009; Ulmer \& Sellnow, 2000). The University maintained that it had a legal obligation and a "moral responsibility" to protect 
survivors (Kaufman, 2016, para. 20), but one reporter countered that it had "a moral and ethical obligation, presumably, to inform people when a faculty member who might be hired elsewhere has been accused of something as egregious as this" (Stripling, 2016, para. 33). By withholding the documents, the administration alienated select stakeholders, including the Kernel, some students and faculty, the Attorney General, external media outlets, and early on, two female survivors. Unable to shield the survivors, empower third parties to expose the alleged wrongdoing of the accused, and operate within legal confines, the University simply could not reconcile all stakeholder interests.

Ethical approaches. The University tried to embrace an ethic of justice in emphasizing its compliance with the legal system. By adhering to a universal standard, the University attempted to appear objective and fair. However, an ethic of justice requires impartiality (Sandin, 2009), and the University also openly claimed to prioritize the survivors and current students over other stakeholders. A key component of an ethic of justice is the ability to resolve conflicting rights (Simola, 2003), which created a double-bind for the University as the two values in question were the survivors' right to privacy and the public's right to know. Favoring one came at the expense of the other, and the situational constraints made it infeasible for the University to employ an ethic of justice.

The University's announcement to prioritize those who it perceived to be most affected by the crisis, survivors and current students, reflected an ethic of care, which accounts for caveats by recognizing the "particular circumstances of individuals" (Xu \& $\mathrm{Li}, 2013$, p. 382) and acknowledges that organizations may not be able to resolve stakeholder conflicts (Simola, 2003). By adopting an ethic of care, the University should have been able to address each stakeholder group in accordance with its own needs, permitting it to thoughtfully explain its stance and underscore its value for all stakeholders. The University adhered to an ethic of care by noting the situational complexities and vocalizing support for survivor privacy. However, its use of legal reasoning to defend its position and the administration's openly discordant relationship with the Kernel often left it appearing detached rather than "sensitive and responsive" to all stakeholders (Tao \& Kim, 2017, p. 693). This 
approach fostered a public perception that these stakeholders did not matter to the University (Editorial Board, 2016c), hindering it from fulfilling conflicting stakeholder responsibilities (Simola, 2003), and crippling the effectiveness of its crisis response.

\section{Critical Applications}

A larger implication of this study reflects the University's reliance on the value of privacy to protect the survivors, ultimately illustrating the concerns advanced by feminist legal scholars who warn that a privacy approach can overshadow the greater issue at hand (Higgins, 1999; Roth, 1999). Gotell (2006) advanced that constructing a privacy argument on behalf of complainants creates a paradox as the "public/private divide" can be "deployed to shield sexual violence from public view" (p. 746). Gotell also offered that privacy appeals can nurture a systemic problem as this argument perpetuates the idea that sexual misconduct is a private matter, allowing it to "become individualized and contained in a moment" (p. 747). Although the case did bring attention to the systemic shortcoming of "passing the trash" in academia, this concern was quickly buried by an avalanche of coverage on the open records debate and lawsuit. The extensive focus on the privacy-transparency tension prohibited the University and media outlets from fully illustrating the complexities of the case and discussing the problems inherent in the justice system and higher education, which was the crux of the survivors' decision to pursue the issue in a public forum in the first place.

Additionally, this case study reflects the fluid dynamics between media coverage and victim reporting in sexual assault/misconduct cases. In October 2016, the University claimed that the number of individuals reporting sexual assault dropped from 59 reports to 38 since the beginning of the case, which it attributed to the extensive media coverage (Blackford, 2016c). While we do not know that the media coverage was the catalyst in the reduced number of reports, this case offers warnings about the effects of extensive coverage of sexual harassment and assault cases. When the complainants went to the University's Title IX office, confidentiality was their key concern, and one survivor emphasized she wanted to avoid the 
courts to protect her identity because of her career (Westerman, 2017). However, the survivors' decision to side with the University as news coverage escalated out of fear that their identities would be revealed demonstrates the potential costs that survivors may encounter when they report these crimes. It also suggests that the substantial attention given to these cases could discourage others from reporting and preserve a culture of silence.

\section{Practical Implications}

This study offers six practical implications for legal crises, and specifically, sexual misconduct and harassment crises. First, legal and public relations practitioners should establish relationships before crises. Blanton recommended practitioners be "at the table" when decisions are made or they will "be behind" (personal communication). He added that the President's office, legal counsel, and public relations team were all involved in drafting messages, underscoring the need to form an interdepartmental crisis management team and coordinate response efforts (Coombs, 2019; Seeger et al., 2003).

Second, organizations must maintain a respectful relationship with the media. The administration and the Kernel publicly disagreed and made scathing comments. Yet, Kirk and Blanton shared that they respected each other (personal communication). Kirk and Poore also noted that the University never attempted to influence the Kernel's coverage (personal communication). Poore added that the University gave the paper a "courteous heads up" before filing the lawsuit and explained that he and Blanton conversed "behind the scenes, trying to solve problems if they were solvable" (personal communication).

Third, even if organizations cannot supply all details, granting media access to relevant parties, including important actors, is essential. The University's reliance on the "Blanton funnel" supported claims in this case that the institution was not being transparent. Some crisis scholars recommend that organizations use multiple individuals to disseminate a message (Sellnow, Ulmer, et al., 2009). Issues such as sexual misconduct are complex and sensitive, and a public relations practitioner may not be the best 
individual to relay messages. The University should have enabled others to discuss the case, including legal counsel, Title IX officers, members of its Violence Intervention and Prevention Center, and other administrators. A chorus of voices highlighting different components and delivering more empathetic statements, while maintaining a consistent narrative, can lend more authenticity and credibility.

Fourth, organizations must explain situational challenges of complex legal issues. Legal counsel claimed that the University attempted to share its legal position in a way that the general public "would readily understand and appreciate" (personal communication). However, Blanton admitted that the University "struggled" to share its perspective (personal communication). The University released only seven public statements compared to the Kernel's 47 articles. Blanton noted the University became more proactive as the case escalated because "other people are going to tell your story ... it's always better to take the shot first" (personal communication).

Fifth, even though an organization may not be able to pacify all stakeholders, it should embrace an ethic of care in its responses by recognizing all concerns. The University's heavy use of the justification and excuse strategies, along with its reliance on legal reasoning, impeded it from acknowledging stakeholders who questioned its actions. Fraustino and Kennedy (2018) proposed that organizations should "communicate with these publics from a stance of care," particularly when dealing with "vulnerable populations" (p. 25). An organization should acknowledge and respectfully engage with all publics, but it may need to prioritize certain stakeholders, such as survivors, during these situations.

Finally, this study advocates for journalists to thoughtfully cover these cases, underscoring the importance of traumainformed reporting (Gearing, 2019). Kirk explained sensitivity was "the hardest part" as "I had to make sure I was not going to cause harm that I could not justify" (personal communication). For the news media to play its significant role in bringing these issues to light, news agencies should cultivate a reputation that ensures survivors are comfortable approaching the outlet because they know their dignity will be maintained. 


\section{Conclusion}

The Kernel and its staff earned national recognition for their reporting. The Kernel received "The Pacemaker" award, known as the "Pulitzer Prize of collegiate journalism," from the Associated Collegiate Press (Nederhoed, 2016) and the College Press "Freedom Award" from the Student Press Law Center (SPLC, 2017). Glamour magazine recognized Kirk as one of its ten "College Women of the Year" (Harder, 2017). Despite these accolades, in August 2017, the circuit court sided with the University, ruling the Attorney General does not have the authority to examine documents if they are protected under FERPA (Blackford, 2017). In May 2019, the Kentucky Court of Appeals overturned that decision. Judge Kelly Thompson, who wrote the three-judge panel's majority opinion, stated the University "has taken the indefensible position that the records are exempt because it says they are and it must be believed" and requested the University review all documents to identify those which are not exempt under privacy rule (Associated Press [AP], 2019, para. 5). The University must then release documents that can be safely redacted, and explain why withheld documents are exempt under law (Cheves, 2019).

As stakeholders demand transparency, organizational decision-makers must identify how to balance information provision and privacy. In the University of Kentucky's sexual misconduct case, the privacy-transparency tension placed administrators in a precarious position. By protecting survivor privacy, the University seemingly put other stakeholders at risk, provoking an outcry that the institution favored its reputation over transparency. This study describes the challenges organizations face when balancing stakeholder interests because of legal restraints or because interests are irreconcilable. Despite demands for an organization to be open, this study demonstrates how prioritizing stakeholders can limit an organization's ability to be forthcoming, particularly when the story the public is interested in is not the organization's story to tell. 


\section{ORID}

Chelsea L. Woods (1) https://orcid.org/00oo-0003-2779-7024

\section{References}

Alpaslan, C. M., Green, S. E., \& Mitroff, I. I. (2009). Corporate governance in the context of crises: Towards a stakeholder theory of crisis management. Journal of Contingencies and Crisis Management, 17(1), 38-49. https://doi.org/10.1111/j.14685973.2009.00555.X

Associated Press [AP]. (2019, May 17). Court: Kentucky University failed to obey open-records law. AP News. Retrieved from web archive at https://apnews.com/9c7827dd498b42bca2afd 828 a49dooed

Benoit, W. L. (1995). Accounts, excuses, apologies: A theory of image restoration discourse. State University of New York Press.

Blackford, L. (2016a, August 8). UK suing two newspapers to appeal open records and open meeting violations. HeraldLeader. Retrieved from web archive at https://web.archive. org/web/20160811172605/https://www.kentucky.com/news/ local/education/article94361187.html

Blackford, L. (2016b, September 8). Beshear seeks to intervene in UK's suit against its student newspaper. Herald-Leader. Retrieved from web archive at https://web.archive.org/ web/20160908164512/http://www.kentucky.com/news/local/ education/article100359972.html

Blackford, L. (2016c, October 27). UK blames Kernel for drop in sex-assault reports; expert calls claim 'shameful.' HeraldLeader. Retrieved from web archive at https://web.archive. org/web/20180425134503/https://www.kentucky.com/news/ local/education/article110836427.html

Blackford, L. (2016d, November 15). Two alleged victims seek to join UK's lawsuit against student newspaper. HeraldLeader. Retrieved from web archive at https://web.archive. org/web/20170601004254/https://www.kentucky.com/news/ local/education/article114862098.html 
Blackford, L. (2017, September 14). UK wins lawsuit to keep sexual harassment documents secret from Attorney General. HeraldLeader. Retrieved from web archive at https://web.archive. org/web/20190913210910/https://www.kentucky.com/news/ local/education/article167139007.html

Brown, N. A., Brown, K. A., \& Billings, A. C. (2015). "May no act of ours bring shame": Fan-enacted crisis communication surrounding the Penn State sex abuse scandal. Communication \& Sport, 3(3), 288-311. https://doi. org/10.1177/2167479513514387

Capilouto, E. (2016a, August 9). The tension of competing values. UK Now. Retrieved from web archive at https://web. archive.org/web/20170908223908/http://uknow.uky.edu/ president-capilouto's-blog/tension-competing-values

Capilouto, E. (2016b, September 21). Continuing conversation on campus safety. UK Now. Retrieved from web archive at https:// web.archive.org/web/20190329020739/https://www.uky.edu/ president/sites/www.uky.edu.president/files/Continuing\%20 Conversation\% 200n\% 20Campus\%2oSafety.pdf

Capilouto, E. (2017, January 24). Ruling in the Kentucky Kernel case. UK Now. Retrieved from web archive at https://web. archive.org/save/http://uknow.uky.edu/blogs/presidentcapilouto-s-blog/ruling-kentucky-kernel-case

Cheves, J. (2019, May 17). UK violated Open Records Act on sexual harassment files, Court of Appeals rules. Herald Leader. Retrieved from web archive at https://web.archive. org/web/20190729081744/https://www.kentucky.com/news/ politics-government/article230522334.html

Coombs, W. T. (2007). Protecting organization reputations during a crisis: The development and application of situational crisis communication theory. Corporate Reputation Review, 10(3), 163-176. https://doi.org/10.1057/palgrave.crr.1550049

Coombs, W. T. (2019). Ongoing crisis communication: Planning, managing, and responding (5th ed.). Sage.

Creswell, J. W. (2013). Qualitative inquiry and research design (3rd ed). Sage. 
Editorial Board. (2016a, August 13). UK's suit for secrecy betrays public interest. Kentucky Kernel. Retrieved from web archive at https://web.archive.org/web/20191019034219/http://www. kykernel.com/opinion/uk-s-suit-for-secrecy-betrays-publicinterest/article_04877cc4-61c1-11e6-8c3b-ef896f3377ao.html

Editorial Board. (2016b, September 15). UK's fight for secrecy leaves truth behind. Kentucky Kernel. Retrieved from web archive at https://web.archive.org/web/20190930034504/http://www. kykernel.com/opinion/uk-s-fight-for-secrecy-leaves-truthbehind/article_e7be8d70-7af8-11e6-a936-6fdb85b1d199.html Editorial Board. (2016c, October 5). Transparency integral for public institutions. Kentucky Kernel. Retrieved from web archive at https://web.archive.org/web/20190727144949/http://www. kykernel.com/opinion/transparency-integral-for-publicinstitutions/article_aod577fe-8b5e-11e6-8odo-9bo318fe97of. html

Fitzpatrick, K. R., \& Rubin, M. S. (1995). Public relations vs. legal strategies in organizational communication decisions. Public Relations Review, 21, 21-33. https://doi.org/10.1016/03638111(95)90037-3

Formentin, M., Bortree, D. S., \& Fraustino, J. D. (2017). Navigating anger in Happy Valley: Analyzing Penn State's Facebookbased crisis responses to the Sandusky scandal. Public Relations Review, 43(4), 671-679. https://doi.org/10.1016/j. pubrev.2017.06.005

Fortunato, J. A. (2008). Restoring a reputation: The Duke University lacrosse scandal. Public Relations Review, 34(2), 116-123. https://doi.org/10.1016/j.pubrev.2008.03.006

Fortunato, J. A., Gigliotti, R. A., \& Ruben, B. D. (2018). Analysing the dynamics of crisis leadership in higher education: A study of racial incidents at the University of Missouri. Journal of Contingencies and Crisis Management, 26(4), 510-518. https:// doi.org/10.1111/1468-5973.12220

Fraustino, J. D., \& Kennedy, A. K. (2018). Care in crisis: An applied model of care considerations for ethical strategic communication. Journal of Public Interest Communications, 2(1), 18-40. https://doi.org/10.32473/jpic.v2.i1.p18 
Freeman, R. E. (1984). Strategic management: A stakeholder approach. Pitman.

Gearing, A. (2019). Reporting child sexual abuse. In A. Luce (Ed.), Ethical reporting of sensitive topics (pp. 49-69). Routledge.

Gibson, D. C., \& Padilla, M. E. (1999). Litigation public relations problems and limits. Public Relations Review, 25(2), 215-233. https://doi.org/10.1016/So363-8111(99)80163-5

Gilligan, C. (1977). In a different voice: Women's conceptions of self and of morality. Harvard Educational Review, 47(4), 481517. https://doi.org/10.17763/haer.47.4.g6167429416hg5lo

Gilligan, C. (1982). In a different voice. Harvard University Press.

Goldfarb, S. F. (2000). Violence against women and the persistence of privacy. Ohio State Law Journal, 61(1), 1-87.

Gotell, L. (2006). When privacy is not enough: Sexual assault complainants, sexual history evidence and the disclosure of personal records. Alberta Law Review, 43(3), 743-778. https://doi. org/10.29173/alr1504

Harder, W. (2017, April 7). Kirk named one of Glamour's 2017 College Women of the Year. UK Now. Retrieved from web archive at https://web.archive.org/web/20170416052935/ https://uknow.uky.edu/student-life/kirk-named-oneglamours-2017-college-women-year

Higdon, J. (2016). U. Kentucky is suing its student newspaper, trying to block sexual assault reporting. The Washington Post. Retrieved from web archive at https://web.archive.org/ web/20161017024352/https://www.washingtonpost.com/ news/grade-point/wp/2016/o9/22/u-kentucky-is-suing-itsstudent-newspaper-trying-to-block-sexual-assault-reporting/

Higgins, T. E. (1999). Reviving the public/private distinction in feminist theorizing symposium on unfinished feminist business. The Chicago-Kent Law Review, 75, 847-867.

Horsley, M. (2016, September 21). UK adds requirement to hiring process to avoid sexual misconduct. Kentucky Kernel. Retrieved from web archive at https://web.archive.org/web/ $20191108133640 /$ http://www.kykernel.com/news/uk-addsrequirement-to-hiring-process-to-avoid-sexual-misconduct/ article_ocba95ee-8060-11e6-a755-f7odd2ef51d8.html 
Huang, Y-H., Lin, Y-H., \& Su, S-H. (2005). Crisis communicative strategies in Taiwan: Category, continuum, and cultural implication. Public Relations Review, 31, 229-238. https://doi. org/10.1016/j.pubrev.2005.02.016

Jin, Y., Park, S-A., \& Len-Ríos, M. E. (2010). Strategic communication of hope and anger: A case of Duke University's conflict management with multiple publics. Public Relations Review, 36(1), 63-65. https://doi.org/10.1016/j.pubrev.2009.08.015

Kaufman, E. (2016, September 1). University of Kentucky sues student newspaper. CNN. Retrieved from web archive at https:// web.archive.org/web/20161206065936/https://www.cnn. com/2016/09/01/us/university-of-kentucky-sues-studentnewspaper-sexual-assault/index.html

Kim, S., Hwang, J., \& Zhang, X. (2016). The impact of organizations' ethical approaches in times of crisis. In B. Brunner (Ed.), The moral compass of public relations (pp. 125-136). New York: Routledge.

Kirk, M. (2016a, August 13). Kernel obtains withheld records; victims say UK trying to protect professor in sexual assault case. Kentucky Kernel. Retrieved from web archive at https://web.archive.org/web/20191018125852/http://www. kykernel.com/news/kernel-obtains-withheld-recordsvictims-say-uk-trying-to-protect/article_1434f 31 e-617511e6-8148-2f5a5ecb7147.html

Kirk, M. (2016b, August 22). Resigned professor accused of research misconduct. Kentucky Kernel. Retrieved from web archive at http://www.kykernel.com/news/resigned-professoraccused-of-research-misconduct/article_b76ef560-687911e6-8650-bf2270122d6b.html

Kirk, M. (2016c, September 21). Safety unfair casualty of upholding UK's image. Kentucky Kernel. Retrieved from web archive at https://web.archive.org/web/20191017141747/http://www. kykernel.com/opinion/safety-unfair-casualty-ofupholding-uk-s-image/article_8e88e268-805d-11e6-ac81$8 \mathrm{f}_{4} \mathrm{c} 8 \mathrm{o6}$ ao6do.html 
Kirk, M., \& Wright, W. (2016, August 8). University to sue Kentucky Kernel in effort to appeal Attorney General's decision. Kentucky Kernel. Retrieved from web archive at https:// web.archive.org/web/20190730162725/http://www.kykernel. $\mathrm{com} /$ news/university-to-sue-kentucky-kernel-in-effort-toappeal-attorney/article_3f 74 eda 4-5dce-1 1 e6-bc 8 e$738 \mathrm{f} 4 \mathrm{ff} 2 \mathrm{~b} 58 \mathrm{f}$.html

Len-Ríos, M. E. (2010). Image repair strategies, local news portrayals and crisis stage: A case study of Duke University's lacrosse team crisis. International Journal of Strategic Communication, 4(4), 267-287. https://doi.org/10.1080/1553 118X.2010.515534

Linsley, P. M., \& Slack, R. E. (2013). Crisis management and an ethic of care: The case of Northern Rock Bank. Journal of Business Ethics, 113(2), 285-295. https://doi.org/10.1007/ s10551-012-1304-8

MacKinnon, C. A. (1991). Reflections on sex equality under law. The Yale Law Journal, 10o(5), 1271-1328. https://doi. org/10.2307/796693

Madden, S. (2018). Engaging collaborative communities: Dialogue and campus sexual assault. Journal of Communication Management, 22(3), 296-308. https://doi.org/10.1108/JCOM06-2017-0064

Manouchehri, K. (2016, November 11). Students march to protest sexual assault at UK. Kentucky Kernel. Retrieved from web archive at https://web.archive.org/web/20191017140554/ http://www.kykernel.com/news/students-march-to-protestsexual-assault-at-uk/article_3ocd63c2-a855-11e6-9814bfdbaeec7dc2.html

Melanson, D. (2016, September 18). Capilouto stands for victims, students. Kentucky Kernel. Retrieved from web archive at https://web.archive.org/web/20190727153443/http://www. kykernel.com/opinion/capilouto-stands-for-victimsstudents/article_13ebbdd4-7df4-11e6-be1e-bbeefb7565ac.html Merlan, A. (2016, August 24). University opts to sue its own newspaper to avoid releasing documents on prof's alleged assaults. Jezebel. Retrieved from web archive at https://web.archive.org/ web/20190823122559/https://jezebel.com/university-opts-tosue-its-own-newspaper-to-avoid-relea-1785690309 
Mitchell, R., Agle, B., \& Wood, D. (1997). Toward a theory of stakeholder identification and salience: Defining the principle of who and what really counts. Academy of Management Review, 22, 853-886. https://doi.org/10.5465/amr.1997.9711022105

Nederhoed, S. (2016, October 26). Kernel Awarded 'Pulitzer Prize of College Journalism.' UK Now. Retrieved from web archive at https://web.archive.org/web/20191108143446/ http://www.kykernel.com/news/kernel-awarded-pulitzerprize-of-college-journalism/article_92857446-9a1e-11e6a1c6-83f39a942084.html

New, J. (2017, January 25). Protecting student privacy, or reputation? Inside Higher Ed. Retrieved from web archive at https://web.archive.org/web/20171108213843/https://www. insidehighered.com/news/2017/01/25/judge-sides-universitykentucky-lawsuit-against-student-newspaper-over-sexual

News Staff. (2016, August 8). UK violated open records law by keeping documents from Kernel, Attorney General rules. Kentucky Kernel. Retrieved from https://web.archive.org/ web/20190612013222/http://www.kykernel.com/news/ukviolated-open-records-law-by-keeping-documents-fromkernel/article_eod738eo-5d7f-11e6-a82f-5fe3ca66ae5d.html

Patton, M. Q. (2002). Qualitative, research \& evaluation methods. Sage.

Rawls, J. (1971). A theory of justice. Harvard University Press.

Rexroat, M. (2017, September 8). UK blames student newspaper for reduced sexual assault reports. Kentucky Kernel. Retrieved from web archive at https://web.archive.org/ web/20190927100134/http://www.kykernel.com/news/ukviolated-open-records-law-by-keeping-documents-fromkernel/article_eod738eo-5d7f-11e6-a82f-5fe3ca66ae 5 d.html

Roth, L. M. (1999). The right to privacy is political: Power, the boundary between public and private, and sexual harassment. Law \& Social Inquiry, 24(1), 45-71. https://doi. org/10.1111/j.1747-4469.1999.tboo792.X

Sandin, P. (2009). Approaches to ethics for corporate crisis management. Journal of Business Ethics, 87, 109-116. https://doi. org/10.1007/s10551-008-9873-2 
Seeger, M. W. (2006). Best practices in crisis communication: An expert panel process. Journal of Applied Communication Research, 34(3), 232-244. https://doi.org/10.1080/ 00909880600769944

Seeger, M. W., Sellnow, T. L., \& Ulmer, R. R. (2003). Communication and organizational crisis. Praeger.

Sellnow, T. L., Littlefield, R. S., Vidoloff, K. G., and Webb, E. M. (2009). The interacting arguments of risk communication in response to terrorist hoaxes. Argumentation and Advocacy, 45, 135-149. https://doi.org/10.1080/00028533.2009.11821703

Sellnow, T. L., Ulmer, R. R., Seeger, M. W., \& Littlefield, R. S. (2009). Effective risk communication: A message-centered approach. Springer.

Simola, S. (2003). Ethics of justice and care in corporate crisis management. Journal of Business Ethics, 46, 351-361. https:// doi.org/10.1023/A:1025607928196

Smith, M. (2016, April 21). Kentucky Kernel appeals UK's decision to deny open records request. Kentucky Kernel. Retrieved from web archive at https://web.archive.org/web/20190928205729/ http://www.kykernel.com/news/kentucky-kernel-appealsuk-s-decision-to-deny-open-records/article_7bdefe76-077811e6-874e-c788691fe710.html

SPLC. (2017, Oct. 26). National award recognizes gutsy Kentucky college journalists whose quest for open records sparked university retaliation. Student Press Law Center. Retrieved from web archive at https://web.archive.org/ web/20191108144213/https://splc.org/2017/10/newsrelease-national-award-recognizes-gutsy-kentuckycollege-journalists-whose-quest-for-open-recordssparked-university-retaliation/

Stripling, J. (2016, December 8). A sex-assault case pits privacy against transparency. The Chronicle of Higher Education. Retrieved from web archive at https://web.archive.org/ web/20170629134828/http://www.chronicle.com/article/ A-Sex-Assault-Case-Pits/238597/ 
Suchman, M. C. (1995). Managing legitimacy: Strategic and institutional approaches. Academy of Management Review, 2o(3), 571-610. https://doi.org/10.2307/258788

Tao, W., \& Kim, S. (2017). Application of two under-researched typologies in crisis communication: Ethics of justice vs. care and public relations vs. legal strategies. Public Relations Review, 43(4), 690-699. https://doi.org/10.1016/j.pubrev.2017.06.003 Trades Union Congress (TUC). (2016). Still just a bit of banter: Sexual harassment in the workplace in 2016. TUC. Retrieved from web archive at https://web.archive.org/ web/20190926202400/https://www.tuc.org.uk/sites/default/ files/SexualHarassmentreport2016.pdf

UK updates policy dealing with sexual assault claims (2018, June 19). Associated Press. Retrieved from web archive at https://web.archive.org/web/20180623020436/https:// apnews.com/28e58504e3e64ebab4594f583a4e262e

Ulmer, R. R. (2001). Effective crisis management through established stakeholder relationships. Management Communication Quarterly, 14, 590-611.https://doi.org/10.1177/089331890114 4003

Ulmer, R. R., \& Sellnow, T. L. (2000). Consistent questions of ambiguity in organizational crisis communication: Jack in the Box as a case study. Journal of Business Ethics, 25(2), 143-155. https://doi.org/10.1023/A:1006183805499

van der Meer, T. G. L. A., Verhoeven, P., Beentjes, H. W. J., \& Vliegenthart, R. (2017). Communication in times of crisis: The stakeholder relationship under pressure. Public Relations Review, 43(2), 426-440. https://doi.org/10.1016/j. pubrev.2017.02.005

Varma, T. M. (2011). Crisis communication in higher education: The use of "negotiation" as a strategy to manage crisis. Public Relations Review, 37(4), 373-375. https://doi.org/10.1016/j. pubrev.2011.08.006

Westerman, A. (2017, September 8). Title IX protects identities but can complicate justice. NPR. Retrieved from web archive at https://web.archive.org/web/20191008093401/https://www. npr.org/2017/01/02/506636941/title-ix-protects-identitiesbut-can-complicate-justice 
Xu, K., \& Li, W. (2013). An ethical stakeholder approach to crisis communication: A case study of Foxconn's 2010 employee suicide crisis. Journal of Business Ethics, 117, 371-386. https://doi. org/10.1007/s10551-012-1522-0

Yin, R. K. (2009). Case study research: Design and methods (4th ed.). Sage. 

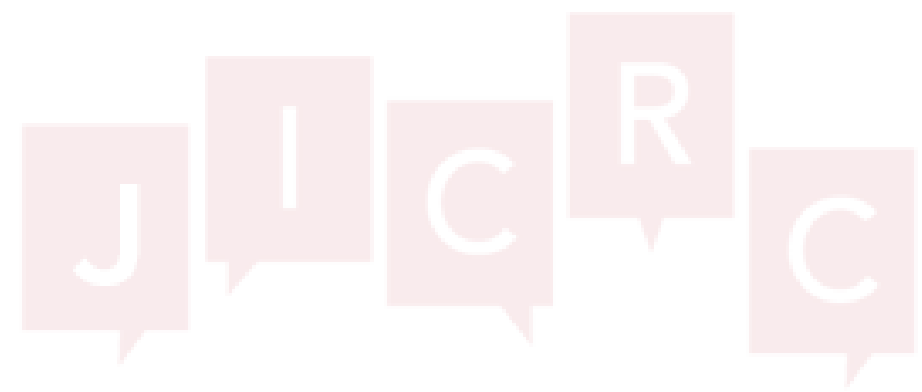